\title{
U.S. historical initial jobless claims. Is it different with the coronavirus crisis? A Fractional Integration analysis
}

\author{
Manuel Monge \\ Universidad Francisco de Vitoria (UFV), Madrid, Spain
}

\begin{abstract}
This research paper makes an empirical analysis based on long memory to understand the historical behavior of initial unemployment claims (ICSA) in the United States (U.S.) during all the recession periods and epidemic diseases such as Severe Acute Respiratory Syndrome (SARS), Middle East Respiratory Syndrome (MERS) and COVID-19 since 1967 applying statistical methods based on long range dependence and fractional differentiation. Using unit root/stationarity tests (ADF, PP and KPSS) we discover that the original time series is stationary $\mathrm{I}(0)$ and the subsamples are non-stationary $\mathrm{I}(1)$. Finally, to analyze the original time series as well as the several periods corresponding to the recessions that occurred in U.S. and the three epidemic diseases, we use AIC and BIC criterion to fit the best ARFIMA model. We conclude that the results display long memory with a degree of integration strictly below $1(\mathrm{~d}<1)$ for the COVID-19 episode and for the rest of the subsamples, except for the original time series and the $2^{\text {nd }}$ subsample. Thus we can conclude that the impacts will be transient and with long lasting effects of shocks and expecting to disappear on their own in long term. Finally, we use a methodology proposed by Bai and Perron to estimate structural breaks not being necessary to know the time of the breaks in advance. The results are similar to those obtained previously.
\end{abstract}

Keywords: Unemployment; Unit Roots, ARFIMA (p,d,q) models.

JEL Classification: C22; E24; J20.

Corresponding author: Assoc. Prof. Manuel Monge

Francisco de Vitoria University (UFV)

Faculty of Law and Business

E-28223 Madrid

Spain

Email: manuel.monge@ufv.es 


\section{Introduction}

Humanity has always lived with microorganisms around it. Some of these microorganisms, controlled and monitored by the health authorities, can cause diseases more or less harmful to health. Following the argue done by Potter (2001) who says that in the past 300 years 10 pandemics are identified. Also, the researcher not reject the hypothesis about other pandemics appear or new medical disasters. This is because Potter (2001) states that these pandemics follow a recurrent but not regular periodic pattern.

Kilbourne (2005) states that in the 20th century the world was hit by the Spanish influenza in 1918 that was the most severe killing at least 40 million people worldwide and 675.000 in the U.S. (Brainerd and Siegler, 2002), the Asian influenza in 1957 and the Hong Kong influenza in 1968. In more recent years we have suffered from other major diseases such as SARS and HIV/AIDS (Jonung and Roeger, 2006)

The last virus to appear is the one called SARS-CoV-2, of the Coronaviridae family, and which causes the COVID-19 disease. According to Hui et al. (2020) and World Health Organization (WHO) ${ }^{1}$, this infectious disease was identified in Wuhan City, China, in December 2019.

Since then, there has been an unprecedented major public health crisis, and not only because of the emergence of a new pathogen affecting humans, but also because health authorities have failed to respond to its spread and expansion.

Many virus containments measures (see Lee et al. 2020; Chen et al. 2020; among others) have been carried out around the world, causing significant economic consequences (see Keogh-Brown et al. 2010). According to OECD (2020), the virus will cause a negative supply shock to the world economy, by forcing factories to shut down and disrupting

\footnotetext{
${ }^{1}$ https://www.who.int/news-room/q-a-detail/q-a-coronaviruses
} 
global supply chains. If we compare it with the SARS crisis, Beutels et al. (2009) carried out a research study for the case of Beijing, using time series of daily and monthly SARS cases and deaths and volume of public train, airplane and cargo transport, tourism, household consumption patterns and gross domestic product growth, where they concluded that much of this consumption was merely postponed. However, the irrecoverable losses related to the tourism was about USD 1.4billion, or 300 times the cost of treatment for SARS cases in Beijing.

Another important mechanism by which a disease has an adverse impact on the long-term growth of the economy is the destruction of human capital. Following the statement done by Barro and Sala-I-Martin (1995), the stock of knowledge embodied in the population is determinant for the long-term growth.

Labor productivity is also affected due to the movement limitation of labor across regions within a country as well as across countries where it is most productive (see for example the analysis of Haacker 2002).

Although various studies have been attempted on the impact of pandemics on macroeconomic variables (in terms of loss of growth and production), there is little consensus in the literature, since the results depend fundamentally on the models used and the availability of data (see Bell and Lewis, 2004).

Focusing on unemployment, in the literature there are several unemployment theories like NAIRU (Friedman 1968 and Phelps 1967, 1968), hysteresis models (see Blanchard and Summers 1986, 1987 and Barro 1988) and structuralist models (Phelps 1994, Pissarides 1990, Blanchard 1999, Phelps 1999, Nickell 1998 y Nickell el al. 2000) that have been statistically analyzed in the literature following the standard unit root tests like Blanchard and Summers (1986) and Alogoskoufis and Manning (1988). Other researchers such as Gordon (1989), Lopez et al. (1996) and Wilkinson (1997) analyzed the statistical 
properties of the hysteresis hypothesis. Others like Mitchell (1993), Bianchi and Zoega (1998) and Papell et al. (2000) studied these properties allowing structural breaks. Amable and Mayhew (2011), Fosten and Ghoshray (2011), Holl and Kunst (2011), King and Morley (2007), Srinivasan and Mitra (2012), among others reported mixed evidence in the more recent literature.

Unit root tests have very low power if the data is fractionally integrated (see Diebold and Rudebush, 1991; Hassler and Wolters, 1994; Lee and Schmidt, 1996), for this reason, and following the research done by Tschernig and Zimmermann (1992), Crato and Rothman (1996), Gil-Alana (2001, 2002), Caporale and Gil- Alana (2007, 2008), Lahiani and Scaillet (2009) among others, our goal is to do a statistical analysis using a fractional integrated (ARFIMA) model from the point of view of supply effects, related to the loss in hours worked. To be more precisely, we examine the time series properties of the weekly initial jobless claims in U.S. over the period January 1, 1967 to March 21, 2020. The contribution of the paper is to analyze the seven periods of recession since 1967 , including the Severe Acute Respiratory Syndrome (SARS), Middle East Respiratory Syndrome (MERS) and COVID-19 crisis. For this purpose, we use methodologies based on the concepts of long-run dependence and long memory using fractional integration techniques. Using these techniques, we can determine if the effect of the shocks is going to be transitory or permanent, and this is important for policy makers and for the implementation of policy measures.

The rest of the paper is structured as follows. Section 2 presents the methodology applied in the paper. Section 3 describes the data and Section 5 presents the main empirical results, while Section 6 concludes the paper. 


\section{Methods}

\subsection{Unit roots methods}

There exist many different ways of testing for unit-roots. The most common ones are those of Fuller (1976) and Dickey and Fuller (1979), the ADF tests. They are asymptotically optimal when the data are stationary. However, in the unit root case there are many other tests available that have greater power. Phillips (1987) and Phillips and Perron (1988) consider tests that employ a non-parametric estimate of the spectral density of $u_{t}$ at the zero frequency, for example, a weighted autocovariance estimate. On the other hand, to test a null hypothesis that an observable time series is stationary around a deterministic trend (i.e. trend-stationary) against the alternative of a unit root, we use the methodology carried out by Kwiatkowski et al. (1992).

\subsection{ARFIMA (p, d, q) model}

To carry out this research based on also fractional integration analysis, we employ long memory methods where the number of differences required to render a series $\mathrm{I}(0)$ stationary is fractional.

Following a mathematical notation, given a time series $x_{t}$, where $t=1,2, \ldots$ is said to follow an integrated of order d process (and denoted as $\left.x_{t} \approx I(d)\right)$ if

$$
(1-L)^{d} x_{t}=u_{t}, \quad t=1,2, \ldots,
$$

Where $d$ can be any real value, $L$ is the lag-operator $\left(L x_{t}=x_{t-1}\right)$ and $u_{t}$ is $\mathrm{I}(0)$, defined as a covariance stationary process with a spectral density function that is positive and finite at the zero frequency. Thus, $u_{t}$ may display some type of time dependence of the weak form, i.e., the type of an Autoregressive Moving Average (ARMA) form such that, for example, if $u_{t}$ is ARMA (p, q), $\mathrm{x}$ is said to be ARFIMA (p, d, q). 
Depending on the value of the parameter $d$, several specifications based on (1) can be observed.

The process would be short memory or $\mathrm{I}(0)$ when $d=0$ in (1). This occur because $x_{t}=$ $u_{t}$. The high degree of association between observations which are far distant in time receive the name of long memory process and occur when $d>0$. Within this last assumption, the process is still covariance stationary if $d<0.5$ because the autocorrelations decay hyperbolically fast.

The reading that we can do on the results obtained from the fractional $\mathrm{d}$ is as follows: we consider a process of reversion which means that the shocks disappear in the long run when $d$ is smaller than 1 . In contrast to the above, the shocks are expected to be permanent when $d \geq 1$.

Although there are several procedures to estimate the degree of long- memory and fractional integration (see Geweke \& Porter-Hudak, 1983; Phillips, 1999, 2007; Sowell, 1992). We base our results on the maximum likelihood procedure (see Sowell, 1992) and we use Akaike information criterion (AIC, Akaike, 1973) and Bayesian information criterion (BIC; Akaike, 1979) to select the right ARFIMA model.

\subsection{Structural breaks}

Finally, we have followed the methodology proposed by Bai and Perron $(1998,2003)$ that permit the modeler to endogenously estimate structural breaks and it is not necessary to know the time of the breaks in advance.

Using this methodology, we assume that $t=1,2,3, \ldots T, m$ unknown breaks and the partitioned time series for $m+1$. 
Some of the coefficients contained in $\rho$ matrix are invariable across all partitions. Others represent the estimated coefficient for each partition 1 to $m+1$ and are located in a series of $\phi$ matrices. The following equation shows this:

$(Y-X \rho-\bar{D} \phi)^{\prime}(Y-X \rho-\bar{D} \phi)=\sum_{i=1 t=T}^{m+1} \sum_{i-1+1}^{T_{i}}\left(y_{t}-x_{t}^{\prime} \rho-d_{t}^{\prime} \phi_{i}\right)^{2}$

Least square is the method used to calculate the coefficients in $\rho$ and $\phi$, that are the parameters and matrices, respectively, used to minimize the number of square errors.

Where the sum of squared residuals is calculated first across all time points in a given segment 1 to $m+1$. Also, $S_{t}\left(T_{1}, T_{2}, \ldots, T_{m}\right)$ represent the sum of squared residuals in $m$-partition and $\left(T_{1}, T_{2}, \ldots, T_{m}\right)$ are specific to the break dates.

\section{Data}

In this paper we used seasonally adjusted weekly initial claims in U.S. over the period January 1, 1967 to June 4, 2020. The data were obtained from the Federal Reserve Bank of St. Louis ${ }^{2}$ and it is shown in figure 1.

To consider the several U.S. recessions we have taken into account the dates provided from Federal Reserve Bank of St. Louis ${ }^{3}$.

Also, we have considered the others disease outbreaks like Severe Acute Respiratory Syndrome (SARS) that according to WHO, began in November 2002 and ended in May $2004^{4}$, Middle East Respiratory Syndrome (MERS) began in September 2012 and it is actually activated, and finally we analyze the COVID-19. To consider the coronavirus crisis $\left(10^{\text {th }}\right.$ recession period), we have taken the start date indicated by Hui et al. (2020) and World Health Organization (WHO) up to the current available data.

The dates that we have used for our analysis are collected in the following table:

\footnotetext{
${ }^{2}$ https://fred.stlouisfed.org/categories/32240

${ }^{3} \mathrm{https} / / /$ fredhelp.stlouisfed.org/fred/data/understanding-the-data/recession-bars/

${ }^{4}$ https://www.who.int/csr/don/2004_05_18a/en/
} 


\begin{tabular}{|c|c|c|}
\hline \multicolumn{3}{|c|}{ Table 1: U.S. Recessions } \\
\hline $1^{\text {st }}$ period & December 1969 & November 1970 \\
\hline $2^{\text {nd }}$ period & November 1973 & March 1975 \\
\hline $3^{\text {rd }}$ period & January 1980 & July 1980 \\
\hline $4^{\text {th }}$ period & July 1981 & November 1982 \\
\hline $5^{\text {th }}$ period & July 1990 & March 1991 \\
\hline $6^{\text {th }}$ period & March 2001 & November 2001 \\
\hline $7^{\text {th }}$ period & December 2007 & June 2009 \\
\hline \multicolumn{3}{|c|}{ Source: Federal Reserve Bank of St. Louis (https://fredhelp.stlouisfed.org/fred/data/understanding-the-data/recession-bars/) } \\
\hline \multicolumn{3}{|c|}{ Pandemic, epidemic diseases } \\
\hline $8^{\text {th }}$ period & November 2002 & May 2004 \\
\hline $9^{\text {th }}$ period & September 2012 & August 2020 \\
\hline $10^{\text {th }}$ period & December 2019 & August 2020 \\
\hline \multicolumn{3}{|c|}{ Source: World Health Organization } \\
\hline \multicolumn{3}{|c|}{ Structural breaks using Bai and Perron $(1998,2003)$} \\
\hline $1^{\text {st }}$ structural break & \multicolumn{2}{|c|}{ January 18,1975} \\
\hline $2^{\text {nd }}$ structural break & \multicolumn{2}{|c|}{ October 29,1983} \\
\hline $3^{\text {rd }}$ structural break & \multicolumn{2}{|c|}{ July 19,2008} \\
\hline $4^{\text {th }}$ structural break & \multicolumn{2}{|c|}{ October 29,2011} \\
\hline $5^{\text {th }}$ structural break & \multicolumn{2}{|c|}{ December 9, 2017} \\
\hline
\end{tabular}

Also, we have also represented in Figure 1 the time series that includes each of these periods in recession and structural breaks. 


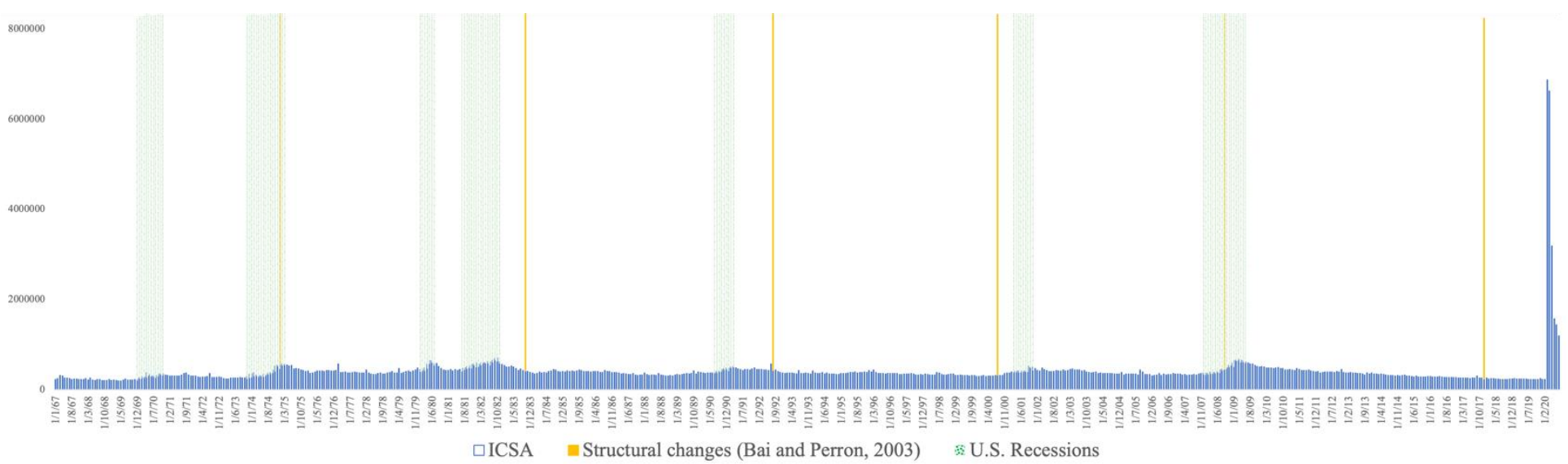

Figure 1. Seasonally adjusted weekly initial claims in U.S. over the period January 1, 1967 to April 4, 2020. (including U.S. Recession periods and Structural Changes according to Bai and Perron (2003) methodology.

\section{Results}

We start the analysis by performing the three standard unit root tests outlined in Section 3. We select the Augmented Dickey-Fuller test (ADF), the Phillips Perron test (PP) and the Kwiatkowski-Phillips-Schmidt-Shin test (KPSS) to examine the statistical properties of the original series of weekly initial jobless claims in U.S. and to obtain robust results. Table 1 displays the results, which suggest that the original data are stationary $I(0)$. The subsamples analyzed in this paper are non-stationary I(1) except the subsample related to MERS pandemic that is stationary $\mathrm{I}(0)$. 


\begin{tabular}{|c|c|c|c|c|c|c|c|}
\hline & \multicolumn{3}{|c|}{ ADF } & \multicolumn{2}{|c|}{$\mathbf{P P}$} & \multicolumn{2}{|c|}{ KPSS } \\
\hline & (i) & (ii) & (iii) & (ii) & (iii) & (ii) & (iii) \\
\hline & \multicolumn{7}{|c|}{ Weekly Initial Jobless Claims in U.S. (ICSA) } \\
\hline Original Data & -9.649 & -17.41 & -17.537 & -10.711 & -10.798 & 0.489119 & 0.208989 \\
\hline & \multicolumn{7}{|c|}{ U.S. Recessions } \\
\hline $1^{\text {st }}$ period & 0.6682 & -2.1386 & -2.849 & -2.3543 & -3.0899 & 0.9054 & 0.1421 \\
\hline $2^{\text {nd }}$ period & 1.6875 & -0.1008 & -1.9283 & -0.2943 & -0.2943 & 1.6708 & 0.4072 \\
\hline $3^{\text {rd }}$ period & 0.9027 & -1.2256 & -0.8547 & -1.307 & -1.137 & 0.9061 & 0.1536 \\
\hline $4^{\text {th }}$ period & 0.8687 & -1.7233 & -2.7205 & -1.5984 & -4.8178 & 1.7167 & 0.1206 \\
\hline $5^{\text {th }}$ period & 1.817 & -0.8598 & -2.9942 & -0.8979 & -3.3645 & 1.0167 & 0.0771 \\
\hline $6^{\text {th }}$ period & 0.6092 & -1.3839 & -2.9097 & -1.2609 & -2.6522 & 0.7153 & 0.1375 \\
\hline $7^{\text {th }}$ period & 1.4095 & -0.8612 & -1.9777 & -0.7466 & -2.2193 & 2.0585 & 0.2331 \\
\hline & \multicolumn{7}{|c|}{ Pandemic, epidemic diseases } \\
\hline $8^{\text {th }}$ period & -0.7024 & -1.2748 & -3.0866 & -1.2024 & -3.2173 & 1.6783 & 0.3668 \\
\hline $9^{\text {th }}$ period & -4.2247 & -16.7232 & -18.5172 & 4.1882 & 4.618 & 0.176 & 0.1738 \\
\hline $10^{\text {th }}$ period & -1.8222 & -2.7509 & -2.7238 & -1.8683 & -1.7552 & 0.242 & 0.1614 \\
\hline & \multicolumn{7}{|c|}{ Structural breaks using Bai and Perron $(1998,2003)$} \\
\hline $1^{\text {st }}$ structural break & 1.3426 & 0.402 & -0.7363 & 0.5046 & -1.0609 & 2.9807 & 0.3475 \\
\hline $2^{\text {nd }}$ structural break & -0.875 & -2.4773 & -2.9779 & -2.6598 & -3.2258 & 2.4732 & 0.7175 \\
\hline $3^{\text {rd }}$ structural break & -0.6336 & -5.164 & -5.2057 & -4.9012 & -4.9603 & 1.062 & 0.3863 \\
\hline
\end{tabular}




\begin{tabular}{|l|l|l|l|l|l|l|l|}
\hline $4^{\text {th }}$ structural break & -0.3232 & -1.1853 & -2.9725 & -1.2803 & -3.3254 & 2.1071 & 0.3099 \\
\hline $5^{\text {th }}$ structural break & -1.1917 & -2.0509 & -7.9014 & -1.7223 & -9.2197 & 5.3117 & 0.5835 \\
\hline
\end{tabular}

Table 2. Unit roots tests. (i) Refers to the model with no deterministic components; (ii) with an intercept, and (iii) with a linear time trend. I reflect $t$-statistic with test critical value at $5 \%$.

Once we have analyzed the original data and the subsamples, we have verified that we must not use the first differences so that our data is stationary I (0) for the original data, for the time series related to MERS pandemic $\left(9^{\text {th }}\right.$ period $)$ and for the $3^{\text {rd }}$ structural break. For the rest, we must use first differences. Due to the low power of the unit root methods under fractional alternatives ${ }^{5}$ presented in table 2, now we are going to use an ARFIMA (p, d, q) model to study the persistence of the original series as the subsamples corresponding to the different periods of recession experienced in the US since 1967. Also, using the methodology proposed by Bai and Perron $(1998,2003)$ we have identified unknown break periods from a specified number of observations, $T$ and $m$ possible breaks that have been analyzed using the ARFIMA model, that we have identified in Table 1 .

To select the right ARFIMA model, we present a methodology based on information criteria such as Akaike information criterion (AIC; Akaike, 1973) and Bayesian information criterion (BIC; Akaike, 1979). Using these criteria for each time series, we show in the following table the correct model that we have chosen:

\section{Information Criteria}

\begin{tabular}{llcc}
\hline Data analyzed & Model Selected & AIC & BIC \\
\hline \hline Original time series & ARFIMA (1, d, 2) & 63009,4 & 63039,1 \\
$1^{\text {st }}$ period & ARFIMA (2, d, 1) & 1011,44 & 1023,04 \\
$2^{\text {nd }}$ period & ARFIMA (2, d, 2) & 1489,55 & 1505,58 \\
$3^{\text {rd }}$ period & ARFIMA (2, d , 1) & 603,585 & 611,789
\end{tabular}

${ }^{5}$ See Diebold and Rudebusch (1991), Hassler and Wolters (1994) and Lee and Schmidt (1996) 


\begin{tabular}{llcc}
$4^{\text {th }}$ period & ARFIMA $(0, \mathrm{~d}, 1)$ & 1490,86 & 1500,02 \\
$5^{\text {th }}$ period & ARFIMA $(0, \mathrm{~d}, 2)$ & 722,535 & 730,723 \\
$6^{\text {th }}$ period & ARFIMA $(2, \mathrm{~d}, 1)$ & 764,654 & 774,48 \\
$7^{\text {th }}$ period & ARFIMA $(1, \mathrm{~d}, 2)$ & 1629,73 & 1644,17 \\
$8^{\text {th }}$ period & ARFIMA $(2, \mathrm{~d}, 2)$ & 1564,29 & 1581,14 \\
$9^{\text {th }}$ period & ARFIMA $(0, \mathrm{~d}, 1)$ & 10135,9 & 10152,1 \\
$10^{\text {th }}$ period & ARFIMA $(0, \mathrm{~d}, 0)$ & 985,84 & 990,59 \\
\hline
\end{tabular}

Structural breaks using Bai and Perron (2003)

\begin{tabular}{cccc}
\hline \hline $1^{\text {st }}$ structural break & ARFIMA (0, d, 0) & 8256,53 & 8268,64 \\
2nd structural break & ARFIMA (2, d, 2) & 9187,58 & 9216,47 \\
$3^{\text {rd }}$ structural break & ARFIMA (1, d, 0) & 24836,1 & 24856,8 \\
$4^{\text {th }}$ structural break & ARFIMA (2, d, 2) & 3348,44 & 3370,43 \\
$5^{\text {th }}$ structural break & ARFIMA (2, d, 2) & 5980,36 & 6006,71 \\
\hline Table 3. Akaike information criterion (AIC) and Bayesian information criterion to choose the right ARFIMA model
\end{tabular}

Table 3 shows the results of AIC and BIC information criterion and the different parameterizations of the ARFIMA (p, d, q) model that we have chosen. The configurations that we have made of the ARFIMA model have been "(0, d, 0)", "(1, d, 0)", "(2, d, 0)", "(0, d, 1)", "(0, d, 2)", "(1, d, 1)", "(1, d, 2)", "(2, d, 1)", "(2, d, 2)".

Once the various configurations were calculated for ARFIMA models and following the selection criteria mentioned above, we are left with those value that have been greater in the AIC and BIC. These models are collected in the table 3.

Taking into consideration that the AR and MA terms capture short-term influences over the ARFIMA $(0, d, 0)$ baseline model and according to the selection criterion explained above, we can observe that for each time series we have several configurations. 
Long memory test on seasonally adjusted weekly initial claims in U.S.

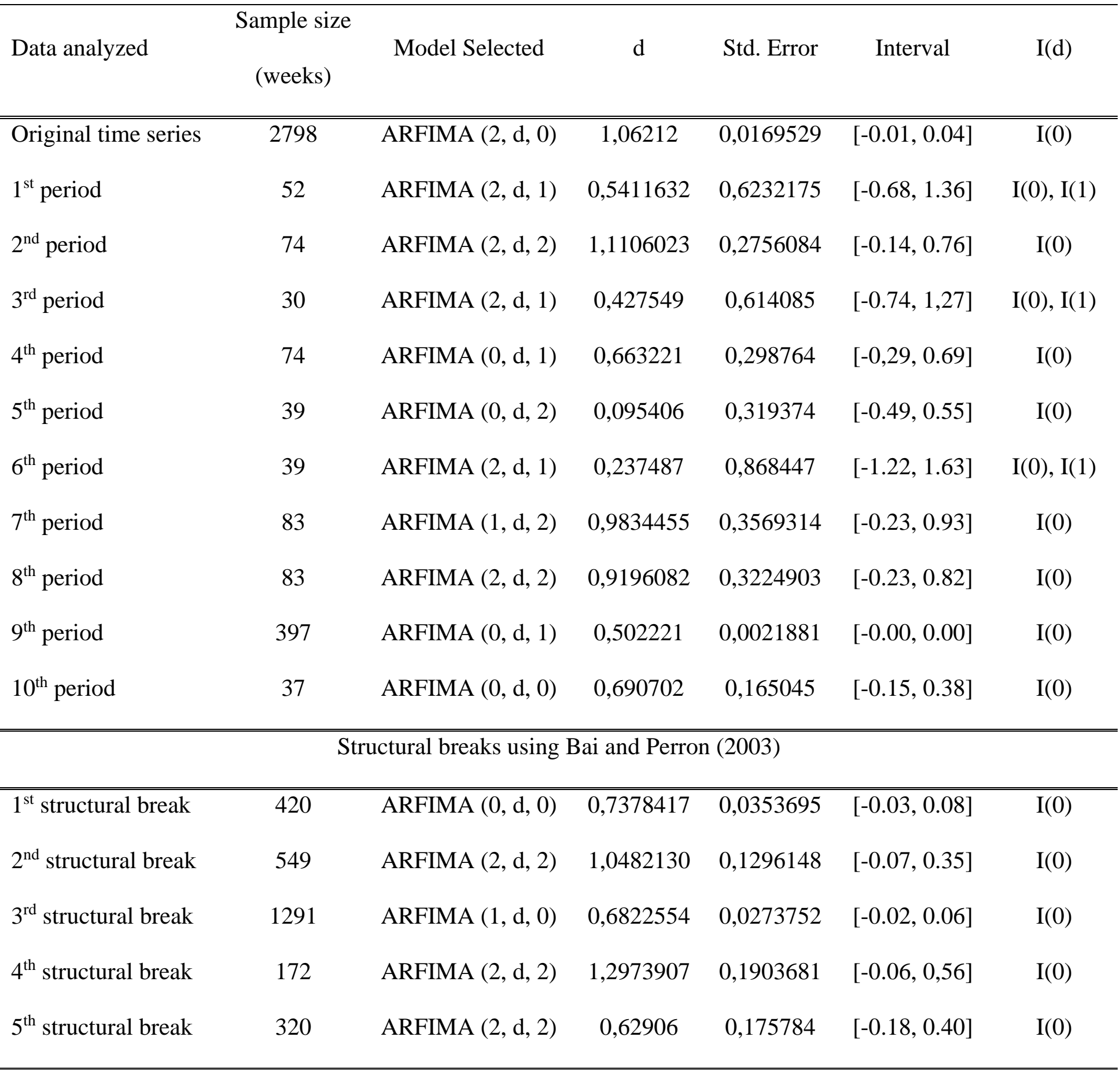

Table 4. Results of long memory tests.

Table 4 display the fractional parameter $\mathrm{d}$ and the AR and MA terms obtained using Sowell's (1992) maximum likelihood estimator of various ARFIMA (p, d, q) specifications with all combinations of $(p, q)$ with $p, q \leq 2$, for seasonally adjusted weekly 
initial claims in U.S. and for each recession subperiods in U.S. localized by Federal Reserve Bank of St. Louis, including coronavirus crisis that started in December 2019. Assuming the explanation done in the Methodology where the process would be short memory or $\mathrm{I}(0)$ when $d=0$. So, we consider a mean reversion process (the shocks disappear in the long run) when $d<1$. On the opposite side, the shock is expected to be permanent when $d \geq 1$. So, we can see that for the subperiods $1^{\text {st }}, 3^{\text {rd }}, 4^{\text {th }}, 5^{\text {th }}, 6^{\text {th }}, 7^{\text {th }}, 9^{\text {th }}$ and $10^{\text {th }}$, where this last one period corresponds to COVID19 episode, the value of $d<1$ implying transitory shocks through with long lasting effects and a low persistence. Mean reversion $(d<1)$ implies transitory shocks and thus, in the event of an exogenous shock if the series is $I(d, d<1)$ the series will return to its original time trend in the future. For the case of the $3 \mathrm{rd}, 5^{\text {th }}$ and 6 th subperiod, the parameter $d$ is lower than 0.5 meaning that the time series analyzed is covariance stationary. We observe mean reversion for these periods where the shock is transitory, and the recovery will take place in a short period of time.

The original time series and the $2^{\text {nd }}$ period the fractional parameter presents a result $d \geq$ 1 , concluding that in these periods are not mean reversion and the shock is expected to be permanent (e.g. lasting forever), causing a change in trend. So, it requires strong measures by the authorities to recover the original trends.

In the case of the subperiods of the structural breaks that we get using the methodology proposed by Bai and Perron $(1998,2003)$, we can observe that the parameter $\mathrm{d}$ is lower than 1 in the $1^{\text {st }}, 3^{\text {rd }}$ and $5^{\text {th }}$ structural break periods. Also, for the $2^{\text {nd }}$ and $4^{\text {th }}$ period $d>$ 1 , but according to the confidence interval we cannot reject the hypothesis of $\mathrm{I}(0)$ in each of the structural changes found.

To conclude and observing the confidence intervals, the $\mathrm{I}(0)$ hypothesis cannot be rejected in all subsamples assuming that the effect of a shock disappear in the short term. 
In the case of the 1st, 3rd and 6th periods we cannot reject the hypothesis of I(1), where the effect of shock persists indefinitely, due to the confidence intervals are very wide (clearly due to the small sample sizes in some of the periods examined).

\section{Conclusions}

In this paper we have examined eleven time series corresponding to the original time series which is seasonally adjusted weekly initial claims in U.S. and the eight subperiods corresponding to each one of the recessions located in time by the Federal Reserve Bank of St. Louis. Also, we have considered the others disease outbreaks like Severe Acute Respiratory Syndrome (SARS) that according to WHO, began in November 2002 and ended in May 2004, Middle East Respiratory Syndrome (MERS) began in September 2012 and it is actually activated, and finally we analyze the COVID-19 that start in December 2019.

Our first focus has been to analyze the statistical properties of these time series using unit roots and fractional integration methods to understand the behavior of the unemployment in the U.S.

We have started to perform several unit root methods, ADF, PP, KPSS. The results suggest that the original time series is stationary $\mathrm{I}(0)$ and the subperiods are nonstationary $\mathrm{I}(1)$.

On the other hand, we have also estimated the differencing parameter $\mathrm{d}$ in terms of fractional model using ARFIMA (p, d, q). To select the right model, we have combine all the possible cases ["(0, d, 0)", "(1, d, 0)", "(2, d, 0)", "(0, d, 1)", "(0, d, 2)", "(1, d, 1)", "(1, d, 2)", "(2, d, 1)", "(2, d, 2)"] to find the best selection criteria following the models proposed by Akaike (1973) and Akaike (1979), which are AIC and BIC respectively. 
Once we have selected the specific ARFIMA model, which as we see for the time series and the respective sub-periods are different, we obtain that for the subperiods $1^{\text {st }}, 3^{\text {rd }}$, $4^{\text {th }}, 5^{\text {th }}, 6^{\text {th }}, 7^{\text {th }}, 9^{\text {th }}$ and $10^{\text {th }}$ the value of $d<1$ implying transitory shocks through with long lasting effects. For the case of the $3 \mathrm{rd}, 5^{\text {th }}$ and 6 th subperiod, the parameter $\mathrm{d}$ is lower than 0.5 meaning that the time series analyzed is covariance stationary. We observe mean reversion for these periods where the shock is transitory, and the recovery will take place in a short period of time.

The original time series and the $2^{\text {nd }}$ period the fractional parameter presents a result $d \geq$ 1 , concluding that in these periods are not mean reversion and the shock is expected to be permanent (e.g. lasting forever), causing a change in trend. So, it requires strong measures by the authorities to recover the original trends.

In the case of the subperiods of the structural breaks that we get using the methodology proposed by Bai and Perron $(1998,2003)$, we can observe that the parameter $\mathrm{d}$ is lower than 1 in the $1^{\text {st }}, 3^{\text {rd }}$ and $5^{\text {th }}$ structural break periods. Also, for the $2^{\text {nd }}$ and $4^{\text {th }}$ period $d>$ 1 , but according to the confidence interval we cannot reject the hypothesis of $\mathrm{I}(0)$ in each of the structural changes found.

To conclude and observing the confidence intervals, the $\mathrm{I}(0)$ hypothesis cannot be rejected in all subsamples assuming that the effect of a shock disappear in the short term. In the case of the 1st, 3rd and 6th periods we cannot reject the hypothesis of I(1), where the effect of shock persists indefinitely, due to the confidence intervals are very wide (clearly due to the small sample sizes in some of the periods examined).

The results presented in this research paper may help to a better understanding of the dynamics of unemployment by policy makers and economic analysts during and after the coronavirus crisis, comparing previous economic and financial crises with the case of the last sub-periods corresponding to a pandemic. 


\section{Declarations section:}

\section{Availability of data and materials}

Not applicable

\section{Competing interest}

Not applicable

\section{Funding}

Not applicable

\section{Authors' contribution}

The author read and approved the final manuscript.

\section{Acknowledgements}

We are grateful to the editor and the anonymous reviewers for their helpful comments.

Manuel Monge gratefully acknowledges financial support from an internal UFV project. 


\section{References}

Akaike, H. (1973). Maximum likelihood identification of Gaussian autoregressive moving average models. Biometrika, 60(2), 255-265.

Akaike, H. (1979). A Bayesian extension of the minimum AIC procedure of autoregressive model fitting. Biometrika, 66(2), 237-242.

Alogoskoufis, G. S., \& Manning, A. (1988). On the persistence of unemployment. Economic Policy, 3(7), 427-469.

Amable, B., \& Mayhew, K. (2011). Unemployment in the OECD. Oxford Review of Economic Policy, 27(2), 207-220.

Bai, J., \& Perron, P. (1998). Estimating and testing linear models with multiple structural changes. Econometrica, 47-78.

Bai, J., \& Perron, P. (2003). Computation and analysis of multiple structural change models. Journal of applied econometrics, 18(1), 1-22.

Barro, R. J. (1988). The persistence of unemployment. The American Economic Review, 78(2), 32-37.

Barro, R. J., \& Sala-i-Martin, X. (1995). Economic Growth McGraw-Hill. New York.

Blanchard, Olivier J. (1999). Wage dynamics: reconciling theory and evidence. American Economic Review, Papers and Proceedings 89: 69-74.

Blanchard, O. J., \& Summers, L. H. (1986). Hysteresis and the European unemployment problem. NBER macroeconomics annual, 1, 15-78.

Blanchard, O. J., \& Summers, L. H. (1987). Hysteresis in unemployment. European Economic Review, 31, 288-295.

Bell, C. \& M. Lewis (2004). The Economic Implications of Epidemics Old and New. World Economics, vol. 5, no. 4, October-December.

Beutels, P., Jia, N., Zhou, Q. Y., Smith, R., Cao, W. C., \& De Vlas, S. J. (2009). The economic impact of SARS in Beijing, China. Tropical Medicine \& International Health, 14, 85-91.

Bianchi, M., \& Zoega, G. (1998). Unemployment Persistence: Does the size of the shock matter?. Journal of Applied Econometrics, 13(3), 283-304.

Brainerd, E., \& Siegler, M. V. (2003). The economic effects of the 1918 influenza epidemic.

Caporale, G. M., \& Gil-Alana, L. A. (2007). Nonlinearities and fractional integration in the US unemployment rate. Oxford Bulletin of Economics and Statistics, 69(4), 521-544. 
Caporale, G. M., \& Gil-Alana, L. A. (2008). Modelling the US, UK and Japanese unemployment rates: Fractional integration and structural breaks. Computational Statistics \& Data Analysis, 52(11), 4998-5013.

Chen, S., Yang, J., Yang, W., Wang, C., \& Bärnighausen, T. (2020). COVID-19 control in China during mass population movements at New Year. The Lancet, 395(10226), 764766.

Crato, N., \& Rothman, P. (1996). Measuring hysteresis in unemployment rates with long memory models. Greenville, Carolina del Sur: Department of Economics, East Carolina University.

Dickey, D. A., \& Fuller, W. A. (1979). Distribution of the estimators for autoregressive time series with a unit root. Journal of the American statistical association, 74(366a), 427431.

Diebold, F.X., \& Rudebush, G. D. (1991). On the power of Dickey-Fuller tests against fractional alternatives. Economics Letters, 35, 155-160.

Fosten, J., \& Ghoshray, A. (2011). Dynamic persistence in the unemployment rate of OECD countries. Economic Modelling, 28(3), 948-954.

Fuller, W. A. (1976). Introduction to Statistical Time Series, New York: JohnWiley. FullerIntroduction to Statistical Time Series1976.

Friedman, M. (1997). The role of monetary policy American Economic Review (1968) 58, March, pp. 1-17. In A Macroeconomics Reader (pp. 176-191). Routledge.

Geweke, J., \& Porter-Hudak, S. (1983). The estimation and application of long memory time series models. Journal of time series analysis, 4(4), 221-238.

Gil-Alana, L. A. (2001). The persistence of unemployment in the USA and Europe in terms of fractionally ARIMA models. Applied Economics, 33(10), 1263-1269.

Gil-Alana, L. A. (2002). Modelling the persistence of unemployment in Canada. International Review of Applied Economics, 16(4), 465-477.

Gordon, R. J. (1989). Hysteresis in history: was there ever a Phillips curve?. The American Economic Review, 79(2), 220-225.

Haacker, M. (2002). The economic consequences of HIV/AIDS in Southern Africa (Vol. 2). International Monetary Fund.

Hassler, U., \& Wolters, J. (1994). On the power of unit root tests against fractional alternatives. Economics Letters, 45(1), 1-5.

Holl, J., \& Kunst, R. M. (2011). Unit root in unemployment-new evidence from nonparametric tests. Applied Economics Letters, 18(6), 509-512. 
Hui, D. S.; Azhar, E. I.; Madani, T. A.; Ntoumi, F.; Kock, R.; Dar, O.; Ippolito, G.; Mchugh, T. D.; Memish, Z. A.; Drosten, C.; Zumla, A.; Petersen, E. (2020). The continuing 2019-nCoV epidemic threat of novel coronaviruses to global health-The latest 2019 novel coronavirus outbreak in Wuhan, China. International Journal of Infectious Diseases, 91, 264-266.

Jonung, L., \& Roeger, W. (2006). The macroeconomic effects of a pandemic in EuropeA model-based assessment. Available at SSRN 920851.

Keogh-Brown, M. R., Wren-Lewis, S., Edmunds, W. J., Beutels, P., \& Smith, R. D. (2010). The possible macroeconomic impact on the UK of an influenza pandemic. Health Economics, 19(11), 1345-1360.

King, T. B., \& Morley, J. (2007). In search of the natural rate of unemployment. Journal of Monetary Economics, 54(2), 550-564.

Kwiatkowski, D., Phillips, P. C., Schmidt, P., \& Shin, Y. (1992). Testing the null hypothesis of stationarity against the alternative of a unit root. Journal of Econometrics, 54(1-3), 159-178.

Lahiani, A., \& Scaillet, O. (2009). Testing for threshold effect in ARFIMA models: Application to US unemployment rate data. International Journal of Forecasting, 25(2), 418-428.

Lee, V. J., Chiew, C. J., \& Khong, W. X. (2020). Interrupting transmission of COVID19: lessons from containment efforts in Singapore. Journal of Travel Medicine.

Lee, D., \& Schmidt, P. (1996). On the power of the KPSS test of stationarity against fractionally-integrated alternatives. Journal of Econometrics, 73(1), 285-302.

León-Ledesma, M. A. (2002). Unemployment hysteresis in the US states and the EU: a panel approach. Bulletin of Economic Research, 54(2), 95-103.

Lopez, H., Ortega, E., \& Ubide, A. J. (1996). Explaining the dynamics of Spanish unemployment.

Mitchell, W. F. (1993). Testing for unit roots and persistence in OECD unemployment rates. Applied Economics, 25(12), 1489-1501.

Murray, C. J., \& Papell, D. H. (2000). Testing for unit roots in panels in the presence of structural change with an application to OECD unemployment. Advances in Econometrics, 15, 223-238.

Nickell, S. (1998). Unemployment: questions and some answers. The Economic Journal, 108(448), 802-816.

Nickell, S., \& Van Ours, J. (2000). The Netherlands and the United Kingdom: a European unemployment miracle?. Economic Policy, 15(30), 136-180.

OECD (2020) "Economic Outlook, Interim Report March 2020.” 
Papell, D. H., Murray, C. J., \& Ghiblawi, H. (2000). The structure of unemployment. Review of Economics and Statistics, 82(2), 309-315.

Phelps, E. S. (1967). Phillips curves, expectations of inflation and optimal unemployment over time. Economica, 254-281.

Phelps, E. S. (1968). Money-wage dynamics and labor-market equilibrium. Journal of Political Economy, 76(4, Part 2), 678-711.

Phelps, E. S. (1994). Structural slumps: The modern equilibrium theory of unemployment, interest, and assets. Harvard University Press.

Phelps, E. S. (1999). Behind this structural boom: the role of asset valuations. American Economic Review, 89(2), 63-68.

Phillips, P. C. (1987). Time series regression with a unit root. Econometrica: Journal of the Econometric Society, 277-301.

Phillips, P. C., \& Perron, P. (1988). Testing for a unit root in time series regression. Biometrika, 75(2), 335-346.

Phillips, P. C. B. (1999). Discrete Fourier transforms of fractional processes. Department of Economics, University of Auckland.

Phillips, P. C. B. (2007). Unit root log periodogram regression. Journal of econometrics, 138(1), 104-124.

Pissarides, C. A. (2000). Equilibrium unemployment theory. MIT Press.

Potter, C. W. (2001). A history of influenza. Journal of applied microbiology, 91(4), 572579.

Song, F. M., \& Wu, Y. (1998). Hysteresis in unemployment: evidence from OECD countries. The Quarterly Review of Economics and Finance, 38(2), 181-192.

Srinivasan, N., \& Mitra, P. (2012). Hysteresis in unemployment: Fact or fiction?. Economics Letters, 115(3), 419-422.

Strazicich, M. C., Tieslau, M., \& Lee, J. (2001). Hysteresis in unemployment? Evidence from panel unit root tests with structural change. Universidad del Norte de Texas, mimeo.

Tschernig, R., \& Zimmermann, K. F. (1992). Illusive persistence in German unemployment. Recherches Économiques de Louvain/Louvain Economic Review, 58(34), 441-453.

Wilkinson, G. (1997). A Micro Approach to the Issue of Hysteresis in Unemployment: Evidence from the 1988? 1990 Labour Market Activity Survey. 